\title{
Effect of artificial aeration on the performance of vertical-flow constructed wetland treating heavily polluted river water
}

\author{
Huiyu Dong ${ }^{1}$, Zhimin Qiang ${ }^{1, *}$, Tinggang $\mathrm{Li}^{1}$, Hui Jin ${ }^{2}$, Weidong Chen ${ }^{2}$ \\ 1. State Key Laboratory of Environmental Aquatic Chemistry, Research Center for Eco-Environmental Sciences, Chinese Academy of Sciences, \\ Beijing 100085, China. E-mail: hydong_st@rcees.ac.cn \\ 2. Environmental Protection Bureau of Lin'an City, Zhejiang Province 311300, China
}

Received 15 May 2011; revised 31 October 2011; accepted 01 November 2011

\begin{abstract}
Three lab-scale vertical-flow constructed wetlands (VFCWs), including the non-aerated (NA), intermittently aerated (IA) and continuously aerated (CA) ones, were operated at different hydraulic loading rates (HLRs) to evaluate the effect of artificial aeration on the treatment efficiency of heavily polluted river water. Results indicated that artificial aeration increased the dissolved oxygen (DO) concentrations in IA and CA, which significantly favored the removal of organic matter and $\mathrm{NH}_{4}{ }^{+}-\mathrm{N}$. The DO grads caused by intermittent aeration formed aerobic and anoxic regions in IA and thus promoted the removal of total nitrogen (TN). Although the removal efficiencies of $\mathrm{COD}_{\mathrm{Cr}}, \mathrm{NH}_{4}{ }^{+}-\mathrm{N}$ and $\mathrm{TN}$ in the three VFCWs all decreased with an increase in HLR, artificial aeration enhanced the reactor resistance to the fluctuation of pollutant loadings. The maximal removal efficiencies of $\mathrm{COD}_{\mathrm{Cr}}, \mathrm{NH}_{4}{ }^{+}-\mathrm{N}^{\text {and }}$ total phosphorus (TP) (i.e., $81 \%, 87 \%$ and 37\%, respectively) were observed in CA at $19 \mathrm{~cm} /$ day HLR, while the maximal TN removal (i.e., $57 \%$ ) was achieved in IA. Although the improvement of artificial aeration on TP removal was limited, this study has demonstrated the feasibility of applying artificial aeration to VFCWs treating polluted river water, particularly at a high HLR.
\end{abstract}

Key words: vertical-flow constructed wetland; artificial aeration; polluted river water; hydraulic loading rate

DOI: $10.1016 / \mathrm{S} 1001-0742(11) 60804-8$

\section{Introduction}

With intensive urbanization and rapid industrialization in recent decades, surface water pollution in China has become a serious issue (Bu et al., 2010; Guo, 2007). Because of the delay to build wastewater treatment systems, the discharge of large quantities of pollutants from residential and industrial areas has not only led to a serious shortage of drinking water but also increased the risk of human health. According to the Report on the State of the Environment in China (SEPA, 2009), 43\% of the rivers are moderately polluted, with more than $18 \%$ of which being too polluted to serve as drinking water sources. At the same time, exceeding $80 \%$ of urban rivers are significantly polluted with some rivers appearing black and malodorous $(\mathrm{Qu}$ and Fan, 2010). Therefore, the improvement on river water quality is currently an urgent task in China.

To simulate the natural wetland processes which are associated with wetland hydrology, soils, microbes and plants, constructed wetland (CW) is a cost-effective and operation-flexible alternative to conventional wastewater treatment processes. Various $\mathrm{CW}$ s have been customized to treat polluted surface water (Lee et al., 2006; Mitsch et al., 2005), domestic, agricultural and industrial wastewaters

\footnotetext{
* Corresponding author. E-mail: qiangz@ rcees.ac.cn
}

(Ngo et al., 2010; Braskerud, 2002). Important factors affecting the treatment performance include the flow type, substrate characteristics, plant species, hydraulic loading rate (HLR) and temperature. HLR, representing the space available for the water to flow through the $\mathrm{CW}$, is a principal parameter for the design and operation of CW. Sakadevan and Bavor (1999) reported that the removal of pollutants in a CW was improved by decreasing HLR when the applied hydraulic retention time (HRT) ranged from 4 to 15 days. A lower HLR implies more contact time and more treatment stability, however, it occupies a larger land area (Kadlec et al., 2010). Considering the limited land area per capita in China, it is more applicable to design and operate the CWs at a high HLR.

In general, the CWs are efficient in removing organic matter and suspended solids, while the low oxygen availability in the substrate results in incomplete nitrification (Stottmeister et al., 2003). The effluent concentrations of total nitrogen (TN) in different $\mathrm{CW}$ s varied widely, many of which failed to meet the local discharge standards (Fraser et al., 2004; Greenway, 2005). In addition, to the $\mathrm{TN}$ concentration, the form of $\mathrm{N}$ is also often a crucial factor affecting the receiving water body. For an instance, except for being toxic to aquatic biota, the associated nitrogenous biochemical oxygen demand of $\mathrm{NH}_{4}{ }^{+}-\mathrm{N}$ can depress dissolved oxygen (DO) levels. 
Although the oxygen availability in the CWs may be enhanced by plants through diffusion of oxygen in rhizomes (Brix, 1997), the extent of plants contribution remains debatable, especially in cold seasons when plants are dormant (Wießner et al., 2002). It was reported that the contribution of plants to pollutants removal was usually less than $10 \%$ (Olson, 1993). Calheiros et al. (2007) also found that there was no significant difference in pollutants removal between the planted and unplanted wetlands during a 17month operation period. The primary role of plants is to hold the wetland components in place and prevent erosion. Therefore, artificial aeration appears necessary when the $\mathrm{CW}$ is operated under a high HLR.

Efforts have been made to improve the performance of CWs by enhancing the oxygen availability (MaltaisLandry et al., 2009). Ong et al. (2010) pointed out that the aerated $\mathrm{CW}$ outperformed the non-aerated one when treating a wastewater containing Acid Orange 7. OuelletPlamondon et al. (2006) found that artificial aeration enhanced pollutants removal in a horizontal subsurfaceflow $\mathrm{CW}$ treating a reconstituted fish farm effluent. Although artificial aeration requires additional energy input, it is profitable especially when the $\mathrm{CW}$ is operated at a high HLR. Since oxygen availability is a good indicator of the diversity and activity of various microbial populations, manipulation of oxygen availability in CWs can encourage the growth of desired microbes to remove target pollutants. Compared with continuous aeration, intermittent aeration not only reduces the operation cost but also creates different redox potentials inside the CWs for the effective removal of TN. However, up to date, few studies have investigated the effects of different aeration modes on the performance of CWs.

In this study, three lab-scale vertical-flow constructed wetlands (VFCWs) were designed and operated with different aeration strategies, i.e., non-aeration (NA), continuous-aeration (CA) and intermittent-aeration (IA), to treat heavily polluted river water. The performances of the three VFCWs were comparatively evaluated through examining the DO profiles and the removal efficiencies of pollutants (i.e., organic matter, N, and P) at different HLRs.

\section{Materials and methods}

\subsection{Reactor configuration and operation}

Three lab-scale VFCW reactors made from polypropylene, including NA, CA and IA ones, were installed indoors and operated at ambient temperature $\left(19 \pm 7^{\circ} \mathrm{C}\right)$ in Lin' an City of Zhejiang Province, China from March to July in 2010. As illustrated in Fig. 1, these cylindrical reactors had an inner diameter of $15 \mathrm{~cm}$ and a height of $80 \mathrm{~cm}$, with four sampling ports situated at 5, 20, 40 and $60 \mathrm{~cm}$ from the bottom, respectively. Each VFCW consisted of two layers, i.e., a top substrate layer $(50 \mathrm{~cm})$ packed with $7-15 \mathrm{~mm}$ gravels and a bottom supporting layer $(10 \mathrm{~cm})$ packed with $18-32 \mathrm{~mm}$ gravels. The supporting layer was to prevent the reactor from clogging and facilitate water flow. The overall porosity of the reactor was approximately

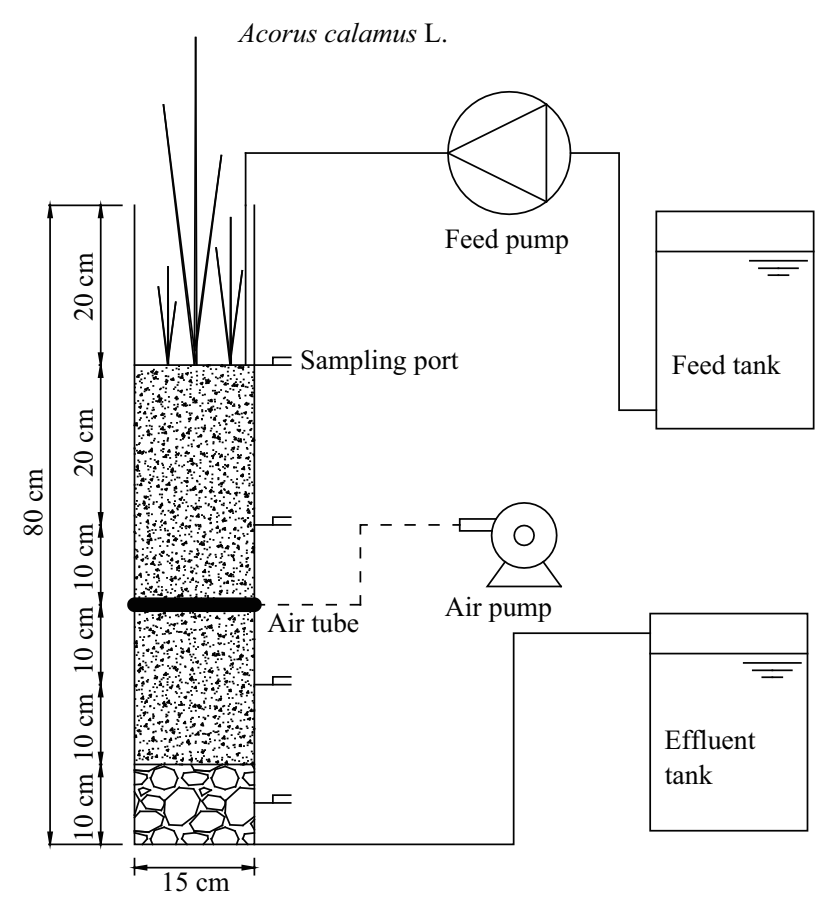

Fig. 1 Schematic diagram of the lab-scale vertical-flow constructed wetlands (VFCWs).

$38 \%$. Reactors CA and IA were equipped with an aeration system consisting of fine-bubble aeration pipe at a height of $30 \mathrm{~cm}$ and an air pump. The aeration rubber pipe (inner diameter $20 \mathrm{~mm}$, length $10 \mathrm{~cm}$ ), which was purchased from a local aquarium store, could generate fine air bubbles with a diameter of about 20-30 $\mu \mathrm{m}$. Intermittent aeration was automatically controlled by a time switch and supplied every other hour.

Activated sludge collected from a local sewage treatment plant was used as inoculated microbial consortium for these VFCWs. Acorus calamus L. was equally transplanted onto the reactor surface, therefore the influence of plants on pollutants removal was almost identical in different VFCWs. River water was periodically collected from a fixed reach of Jinxi River in Lin'an City. The major characteristics of the river water were as follows: $\mathrm{COD}_{\mathrm{Cr}} 65-158 \mathrm{mg} / \mathrm{L}, \mathrm{BOD}_{5} 32-72 \mathrm{mg} / \mathrm{L}, \mathrm{NH}_{4}{ }^{+}-\mathrm{N} 3.5-$ $10.6 \mathrm{mg} / \mathrm{L}$, TN $5.8-12.7 \mathrm{mg} / \mathrm{L}$, total phosphorus (TP) $0.60-3.85 \mathrm{mg} / \mathrm{L}$, and $\mathrm{pH}$ 6.9-7.8. This river was mainly polluted by the illegal drainage of some domestic wastewater. The ratios of $\mathrm{BOD}_{5} / \mathrm{COD}_{\mathrm{Cr}}$ were usually greater than 0.45 , indicating that the collected river water was readily biodegradable. The river water was continuously fed into the VFCWs from the same feed tank by using a metering pump. The three VFCWs were operated under the same HLRs (19, 38 and $76 \mathrm{~cm} /$ day) with each HLR lasting for 4 weeks. When the VFCWs reached steady-state at the HLR of $38 \mathrm{~cm} /$ day, as indicated by a stable removal of major pollutants (i.e., COD and $\mathrm{NH}_{4}{ }^{+}-\mathrm{N}$ ), samples were taken from the four sampling points along the reactor and then analyzed.

\subsection{Sample collection and analysis}

To allow plants growth and microbes acclimatization, the three VFCWs were pre-operated for 20 days. Water tem- 
perature, $\mathrm{pH}$ and DO concentration were simultaneously measured on site by use of a portable multi-parameter meter (Multi 340i, WTW, Germany). The concentrations of chemical oxygen demand $\left(\mathrm{COD}_{\mathrm{Cr}}\right)$, ammonia nitrogen $\left(\mathrm{NH}_{4}{ }^{+}-\mathrm{N}\right), \mathrm{TN}$, and TP were analyzed according to Hach methods 8000, 10031, 10071, 8190 with a Hach DR5000 UV-Vis spectrophotometer (Loveland Co., USA).

\section{Results and discussion}

\subsection{DO profile along VFCW beds}

DO plays an important role in the activity of microbes in wetlands. Nitrification occurs under aerobic condition while denitrification occurs under anoxic condition. To achieve the simultaneous removal of organic matter $\left(\mathrm{COD}_{\mathrm{Cr}}\right)$ and nutrients $(\mathrm{N}, \mathrm{P})$, the aerobic and anoxic regions in wetlands need optimization depending on wastewater characteristics and operational manipulation. Although the VFCWs have higher mass transfer efficiency than the horizontal-flow ones, the DO concentrations (averaged over three tested HLRs) in the $5-40 \mathrm{~cm}$ region above the reactor bottom were below $1 \mathrm{mg} / \mathrm{L}$ in NA, which could inhibit the nitrification process (Fig. 2). It was reported that no obvious nitrification was observed when the DO concentration was lower than $0.5 \mathrm{mg} / \mathrm{L}$ (Vymazal, 2007). As shown in Fig. 2, artificial aeration significantly improved the oxygen availability in the VFCWs. The average DO concentrations increased from 0.4 to $2.1,0.7$ to 3.0 , and 1.3 to $4.4 \mathrm{mg} / \mathrm{L}$ in NA, IA and CA along the reactor bed, respectively. Although all the DO concentrations in IA and CA appeared to exceed that required for anoxic condition (i.e., $0.2-0.5 \mathrm{mg} / \mathrm{L}$ ), anoxic regions could still exist in the aerated VFCWs due to the stratification of biofilms (spatially in IA and CA) and particularly the operation mode of intermittent aeration (temporally in IA), which would facilitate denitrification.

\subsection{COD $_{\mathrm{Cr}}$ removal}

Three HLRs (19, 38 and $76 \mathrm{~cm} /$ day), which gave the nominal HRTs of 2,1 and 0.5 days, respectively, were se-

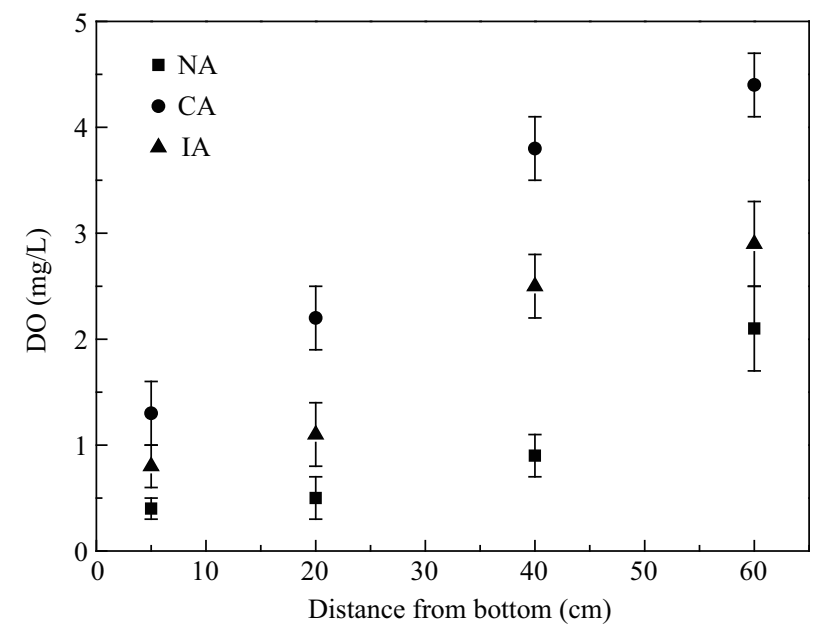

Fig. 2 DO profiles along the studied vertical flow construed wetlands (VFCWs). NA: non-aerated reactor; CA: continuously aerated reactor; IA: intermittently aerated reactor. lected to evaluate the effect of artificial aeration on organic matter $\left(\mathrm{COD}_{\mathrm{Cr}}\right)$ removal. Figure 3 shows the variation of effluent $\mathrm{COD}_{\mathrm{Cr}}$ and average removal efficiencies under three aeration modes at different HLRs. Results indicate that with the increase of HLR from 19 to $76 \mathrm{~cm} /$ day, the removal efficiencies of $\mathrm{COD}_{\mathrm{Cr}}$ in all three VFCWs decreased. Increasing HLR would reduce the contact time between wastewater and microbes, enhance the detachment of microbes off substrate surfaces, and decrease the oxygen availability (Toet et al., 2005). However, as the HLR was increased from 38 to $76 \mathrm{~cm} /$ day, the COD $_{\mathrm{Cr}}$ removal efficiency of NA dropped obviously from $57 \%$ to $48 \%$, while the performance of CA and IA remained quite stable. It is seen that artificial aeration could increase the resistance of VFCW to HLR fluctuation. Although organic matter can be degraded both aerobically and anaerobically by heterotrophic bacteria in the wetlands depending on local DO concentrations, aerobic degradation is usually more important (Vymazal, 1999). Therefore, the $\mathrm{COD}_{\mathrm{Cr}}$ removal efficiency was positively correlated with the aeration condition (CA > IA > NA, Fig. 3). Increasing DO concentration through artificial aeration could not only enhance microbial activity but also accelerate the diffusion of pollutants (Ouellet-Plamondon et al., 2006).

Figure 4 compares the profiles of $\mathrm{COD}_{\mathrm{Cr}}$ concentrations along the VFCWs at $38 \mathrm{~cm} /$ day HLR. Due to the higher DO concentrations in the top $40-60 \mathrm{~cm}$ region, $39 \%, 48 \%$ and $57 \%$ of the influent $\mathrm{COD}_{\mathrm{Cr}}$ was removed there in NA, IA and CA, respectively. In accordance with the decreased DO concentrations, the removal of $\mathrm{COD}_{\mathrm{Cr}}$ slowed down as the medium deepened. It is seen that DO concentration is a critical factor responsible for $\mathrm{COD}_{\mathrm{Cr}}$ removal.

\subsection{Nitrogen removal}

Nitrogen removal in CWs occurs through adsorption, assimilation into biomass, ammonia volatilization and coupled nitrification/denitrification, among which the nitrification/denitrification process is the most important (Nurk et al., 2005). As an aerobic chemo-autotrophic microbial process, nitrification is a primary prerequisite for nitrogen

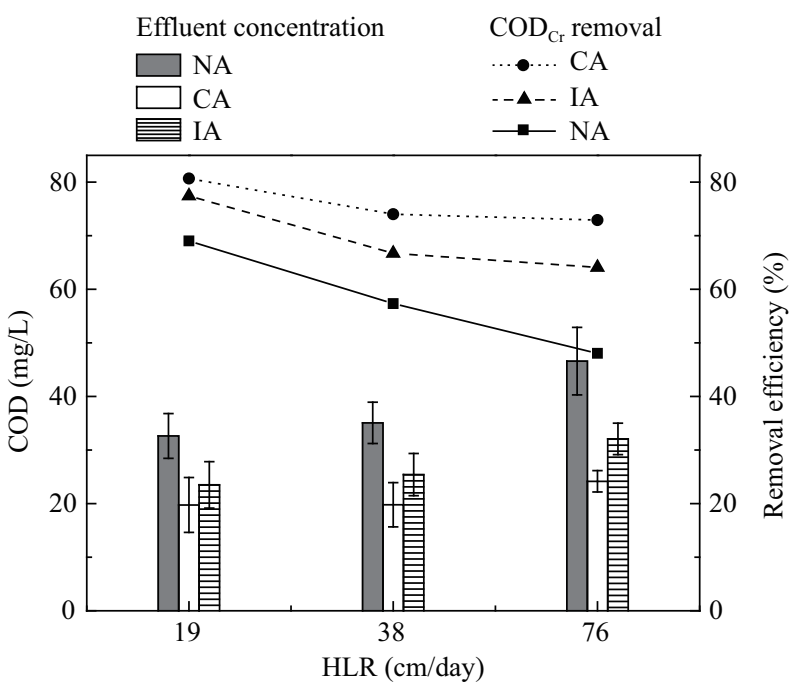

Fig. 3 Effluent concentrations and corresponding removal efficiencies of $\mathrm{COD}_{\mathrm{Cr}}$ at different hydraulic loading rates (HLRs). 


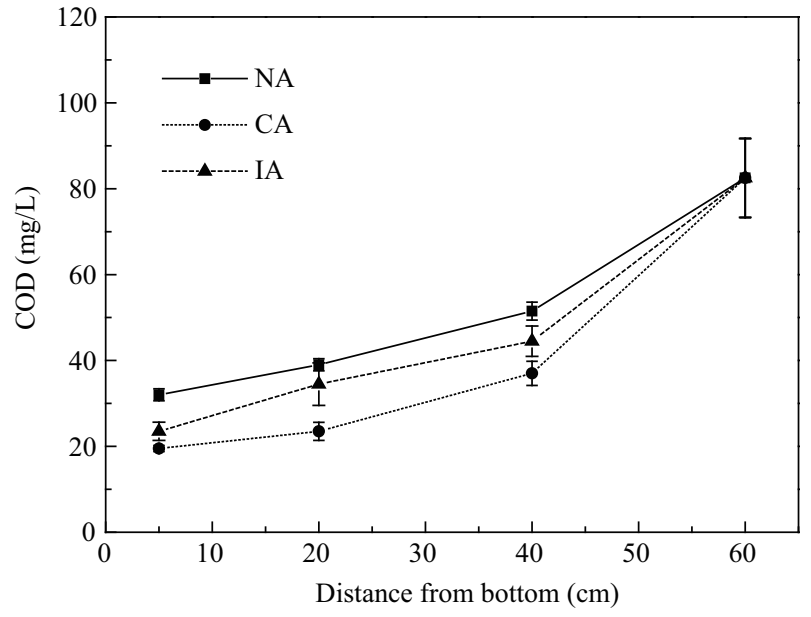

Fig. 4 COD $_{\mathrm{Cr}}$ concentrations along the studied VFCWs (HLR 38 $\mathrm{cm} /$ day).

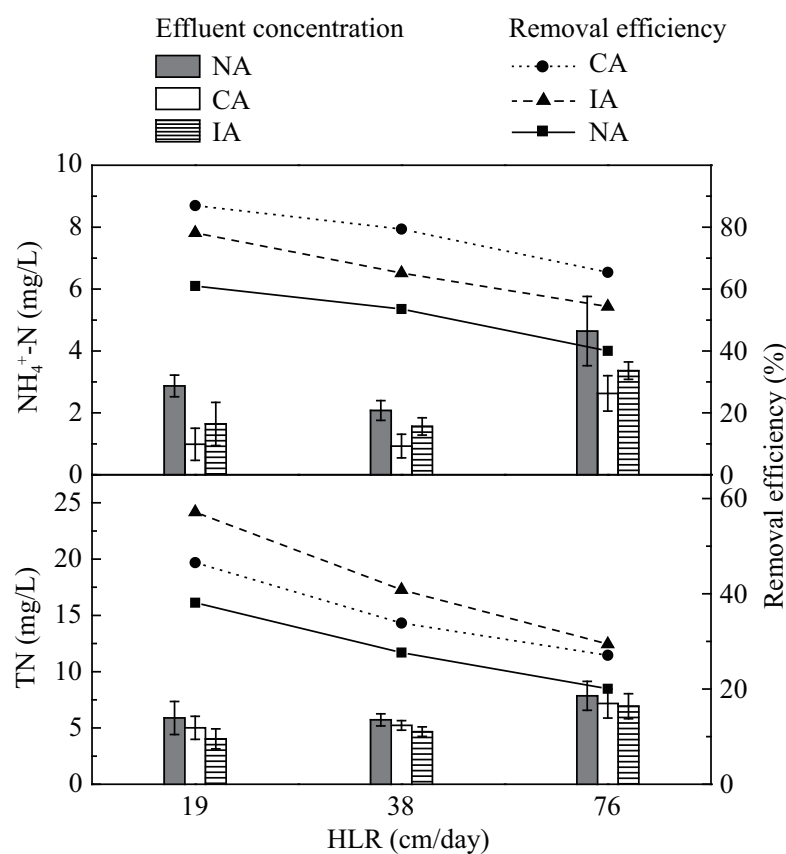

Fig. 5 Effluent concentrations and corresponding removal efficiencies of $\mathrm{NH}_{4}{ }^{+}-\mathrm{N}$ and $\mathrm{TN}$ at different HLRs.

removal in wetlands. Figure 5 shows that the $\mathrm{NH}_{4}{ }^{+}-\mathrm{N}$ removal efficiencies of all three VFCWs were greatly influenced by the HLR. With an increase of HLR from 19 to $76 \mathrm{~cm} /$ day, the average $\mathrm{NH}_{4}{ }^{+}-\mathrm{N}$ removal efficiencies of NA, CA and IA dropped from $61 \%$ to $40 \%, 87 \%$ to $65 \%$, and $78 \%$ to $54 \%$, respectively. Being different from $\mathrm{COD}_{\mathrm{Cr}}$ removal, the $\mathrm{NH}_{4}{ }^{+}-\mathrm{N}$ removal was more sensitive to the change of HLR. A higher HLR would favorably select heterotrophic bacteria against autotrophic ammonia oxidation bacteria through competition for substrates and DO, thus rapidly inhibiting the removal of $\mathrm{NH}_{4}{ }^{+}-\mathrm{N}$. Results also show that artificial aeration significantly enhanced $\mathrm{NH}_{4}{ }^{+}-\mathrm{N}$ removal in VFCWs. For example, the average removal efficiencies of $\mathrm{NH}_{4}{ }^{+}-\mathrm{N}$ in NA, IA and CA were $54 \%, 65 \%$ and $80 \%$ at $38 \mathrm{~cm} /$ day HLR, respectively. Therefore, DO is also a critical factor governing the process of nitrification. Although the plant roots can release oxygen in rhizosphere (Bodelier et al., 1996), DO deficit often occurs in the interior region of wetlands which limits the nitrification efficiency. Since nitrification and denitrification are two operationally separate processes (either temporally or spatially) which respectively require aerobic and anoxic conditions, the rate of nitrification significantly impacts the removal of TN).

The removal efficiency of TN significantly dropped with an increase of HLR in the studied VFCWs (Fig. 5). For an instance, the removal efficiency of TN in IA decreased from $57 \%$ at $19 \mathrm{~cm} /$ day to $29 \%$ at $76 \mathrm{~cm} /$ day. Although prevailing anoxic and anaerobic conditions in NA offered suitable conditions for denitrification, the supply of nitrate was limited. The improvement on oxygen availability in IA and CA strengthened TN removal. It is particularly noted that IA achieved a higher TN removal efficiency than CA, although the former showed a relatively lower nitrification rate. Denitrification can be limited in CWs by lack of labile carbon, lack of nitrate, or excessive oxygen supply (Tanner et al., 2002; Tanner and Kadlec, 2003). In IA, the DO and pollutant grads resulted in different microenvironments in the attached biofilms, thus facilitating the denitrification process.

To further elaborate on the above results, the concentration profiles of $\mathrm{NH}_{4}{ }^{+}-\mathrm{N}, \mathrm{NO}_{3}{ }^{-} \mathrm{N}$ and $\mathrm{TN}$ along the VFCWs at $38 \mathrm{~cm} /$ day HLR are shown in Fig. 6. Results indicate that the $\mathrm{NH}_{4}{ }^{+}-\mathrm{N}$ profile differed remarkably from the $\mathrm{COD}_{\mathrm{Cr}}$ profile (Fig. 4). While more than $40 \%$ of $\mathrm{COD}_{\mathrm{Cr}}$ was removed in the top region $(40-60 \mathrm{~cm})$ of all the three VFCWs, the removal of $\mathrm{NH}_{4}{ }^{+}-\mathrm{N}$ in this region was rather limited especially when comparing the data under artificial aeration conditions. However, the $\mathrm{NH}_{4}{ }^{+}-\mathrm{N}$ removal was accelerated as the reactor deepened. It is

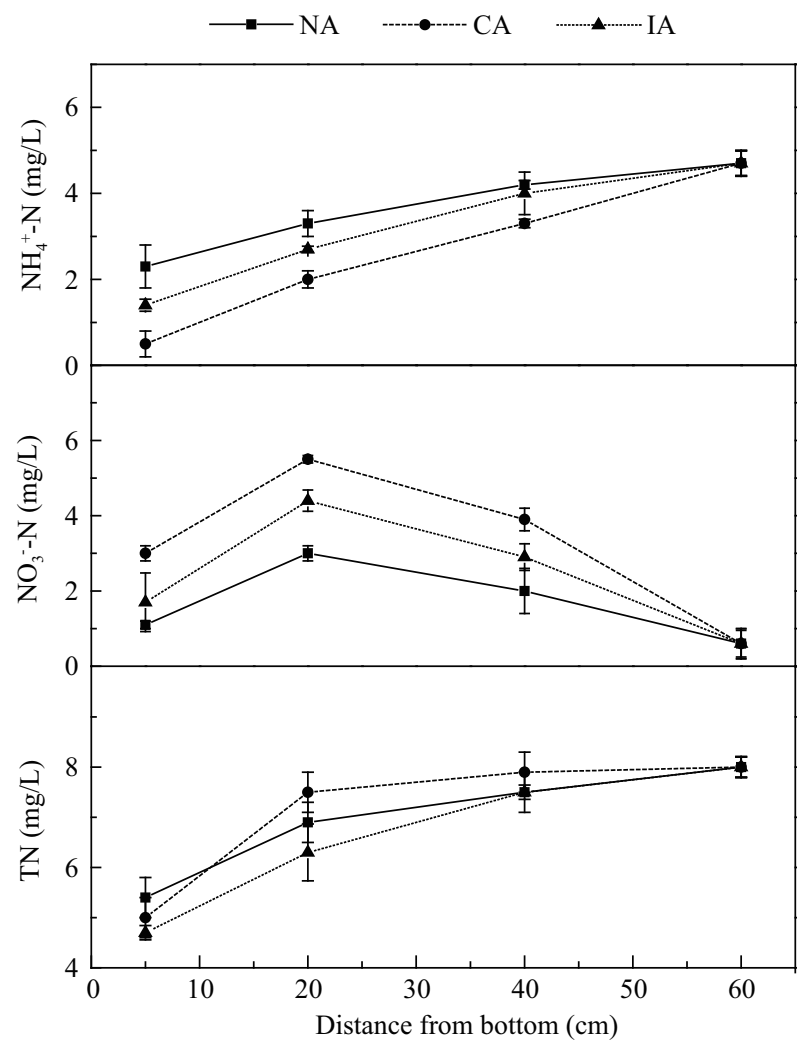

Fig. $6 \mathrm{NH}_{4}^{+}-\mathrm{N}, \mathrm{NO}_{3}{ }^{-}-\mathrm{N}$ and $\mathrm{TN}$ concentrations along the studied VFCWs (HLR $38 \mathrm{~cm} /$ day). 
inferred that heterotrophic bacteria responsible for $\mathrm{COD}_{\mathrm{Cr}}$ removal predominated in the upper region $(40-60 \mathrm{~cm})$ while nitrifying bacteria became advantage strains in the lower region $(5-40 \mathrm{~cm})$. Heterotrophic bacteria usually prevail over the autotrophic ammonia oxidation bacteria in biofilms until the organic matter decreased to some extent along the flow path of wastewater. Nurk et al. (2005) also observed a higher nitrification rate close to the outlet due to a decrease of organic matter and/or toxic substances.

The higher nitrification bioactivity in $\mathrm{CA}$ and IA was also manifested by the $\mathrm{NO}_{3}{ }^{-}-\mathrm{N}$ concentration profile (Fig. 6). Results show that the $\mathrm{NO}_{3}{ }^{-}-\mathrm{N}$ concentrations in NA were always lower than those in CA and IA. From the $\mathrm{TN}$ concentration profile, it is clear that most of TN was removed in the bottom region of the VFCWs (i.e., 5-20 $\mathrm{cm})$. The intermittent aeration in IA improved the removal of $\mathrm{NH}_{4}{ }^{+}-\mathrm{N}$ as compared with $\mathrm{NA}$, and meanwhile the stratification of aerobic and anoxic zones in IA facilitated denitrification as compared with CA. From the practical point of view, intermittent aeration decreases the demand for power supply (thus saving operational costs) compared with continuous aeration, and at the same time achieves a higher TN removal.

Figure 7 shows that the mass removal rates of both $\mathrm{NH}_{4}{ }^{+}-\mathrm{N}$ and $\mathrm{TN}$ increased with an increase of nitrogen mass loading rate in the tested range of $0-9 \mathrm{~g} /\left(\mathrm{m}^{2} \cdot\right.$ day $)$. The maximal mass removal rate was observed as 5.5 $\mathrm{g} /\left(\mathrm{m}^{2} \cdot\right.$ day $)$ for $\mathrm{NH}_{4}{ }^{+}-\mathrm{N}$ in $\mathrm{CA}$ and about $3.0 \mathrm{~g} /\left(\mathrm{m}^{2} \cdot\right.$ day $)$ for $\mathrm{TN}$ in IA. Since the removal efficiencies of $\mathrm{NH}_{4}{ }^{+}-\mathrm{N}$ and TN (calculated by concentration) decreased with an increase of HLR (Fig. 5), there exists an optimal influent nitrogen loading rate at which the removal of $\mathrm{NH}_{4}{ }^{+}-\mathrm{N}$ and $\mathrm{TN}$ can be maximized.

\subsection{Total phosphorus removal}

The major processes responsible for phosphorus removal in wetlands include medium adsorption, chemical precipitation and assimilation into microbial and plant biomass

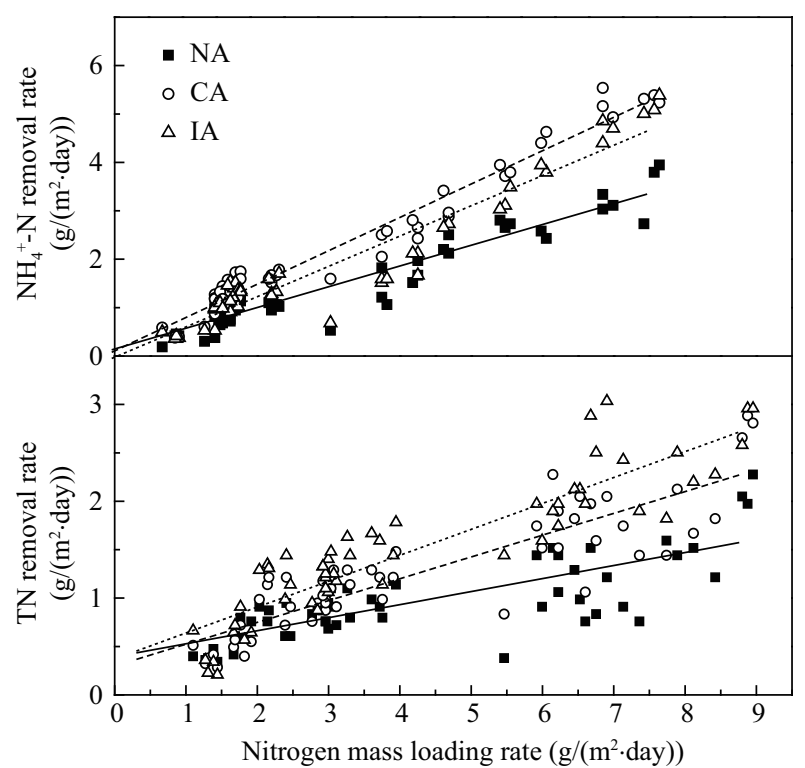

Fig. 7 Mass removal rates of $\mathrm{NH}_{4}{ }^{+}-\mathrm{N}$ and $\mathrm{TN}$ as a function of nitrogen mass loading rate.

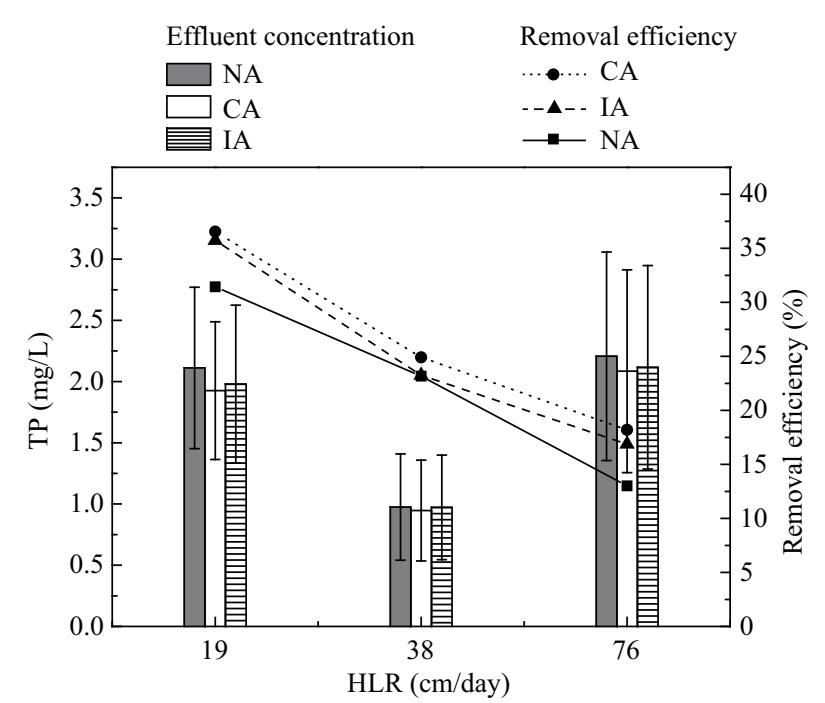

Fig. 8 Effluent concentrations and corresponding removal efficiencies of TP at different HLRs.

(Arias et al., 2001; Tanner et al., 1999). Interception of P-containing suspended solids also makes a certain contribution. Figure 8 shows that the average removal efficiency of TP in all three VFCWs rapidly dropped with an increase in HLR. Moreover, the gradual saturation of the adsorption sites on media could also lead to a decrease in TP removal. Although an increased DO concentration may promote TP adsorption and precipitation to the media (De-Bashan and Bashan, 2004), artificial aeration only had a slight improvement on TP removal. The average removal efficiencies of TP in NA, IA and CA at $19 \mathrm{~cm} /$ day HLR were $31 \%, 35 \%$ and $37 \%$, respectively. It is noted that the relatively lower effluent concentrations of TP at 38 $\mathrm{cm} /$ day was due to its lower influent concentrations. The high effluent concentrations of TP increased the risk of eutrophication in receiving waters. The removal of TP needs to be improved by using media of high adsorption capacity in future study.

\section{Conclusions}

This work investigated the effect of artificial aeration on the performance of three lab-scale VFCWs treating heavily polluted river water at high HLRs. Based on the obtained results, the following conclusions can be drawn: (1) Artificial aeration significantly improved the oxygen availability and thus enhanced the removal of $\mathrm{COD}_{\mathrm{Cr}}$ and $\mathrm{NH}_{4}{ }^{+}-$ $\mathrm{N}$ in the VFCWs. (2) Intermittent aeration was optimal for $\mathrm{TN}$ removal, which facilitated denitrification due to both spatial and temporal formations of anoxic zones in the VFCWs. Although continuous aeration achieved the highest nitrification rate, the denitrification process was notably suppressed due to an excessive oxygen supply. Taking account of both operational costs and treatment efficiency, intermittent aeration is the optimal mode for VFCWs. (3) HLR had a crucial impact on the removal of organic matter and nutrients. Increasing HLR significantly reduced the performance of VFCWs. However, artificial aeration could enhance the resistance of VFCWs to the fluctuation of pollutant loadings. 


\section{Acknowledgments}

The authors greatly acknowledge the financial support from the Ministry of Environmental Protection (No. 2008ZX07101-006-08) and the Ministry of Science and Technology of China (No. 2009BAC57B02).

\section{References}

Arias C A, Del Bubba M, Brix H, 2001. Phosphorus removal by sands for use as media in subsurface flow constructed reed beds. Water Research, 35(5): 1159-1168.

Bodelier P L E, Libochant J A, Blom C W P M, Laanbroek H J, 1996. Dynamics of nitrification and denitrification in root-oxygenated sediments and adaptation of ammoniaoxidizing bacteria to low-oxygen or anoxic habitats. Applied and Environmental Microbiology, 62(11): 41004107.

Braskerud B C, 2002. Factors affecting phosphorus retention in small constructed wetlands treating agricultural non-point source pollution. Ecological Engineering, 19(1): 41-61.

Brix H, 1997. Do macrophytes play a role in constructed treatment wetlands? Water Science and Technology, 35(5): $11-17$.

Bu H M, Tan X, Li S Y, Zhang Q F, 2010. Temporal and spatial variations of water quality in the Jinshui River of the South Qinling Mts., China. Ecotoxicology and Environmental Safety, 73(5): 907-913.

Calheiros C S C, Rangel A O S S, Castro P M L, 2007. Constructed wetland systems vegetated with different plants applied to the treatment of tannery wastewater. Water Research, 41(8): 1790-1798.

De-Bashan L E, Bashan Y, 2004. Recent advances in removing phosphorus from wastewater and its future use as fertilizer (1997-2003). Water Research, 38(19): 4222-4246.

Fraser L H, Carty S M, Steer D, 2004. A test of four plant species to reduce total nitrogen and total phosphorus from soil leachate in subsurface wetland microcosms. Bioresource Technology, 94(2): 185-192.

Greenway M, 2005. The role of constructed wetlands in secondary effluent treatment and water reuse in subtropical and arid Australia. Ecological Engineering, 25(5): 501-509.

Guo L, 2007. Ecology-Doing battle with the green monster of Taihu Lake. Science, 317(5842): 1166.

Kadlec R H, Roy S B, Munson R K, Charlton S, Brownlie $\mathrm{W}, 2010$. Water quality performance of treatment wetlands in the Imperial Valley, California. Ecological Engineering, 36(8): 1093-1107.

Lee B H, Scholz M, Horn A, 2006. Constructed wetlands: Treatment of concentrated storm water runoff (Part A). Environmental Engineering Science, 23(2): 320-331.

Maltais-Landry G, Maranger R, Brisson J, 2009. Effect of artificial aeration and macrophyte species on nitrogen cycling and gas flux in constructed wetlands. Ecological Engineering, 35(2): 221-229.

Mitsch W J, Day J W, Zhang L, Lane R R, 2005. Nitratenitrogen retention in wetlands in the Mississippi river basin. Ecological Engineering, 24(4): 267-278.

Ngo T D T, Konnerup D, Schierup H H, Nguyen H C, Le A T, Brix H, 2010. Kinetics of pollutant removal from domestic wastewater in a tropical horizontal subsurface flow constructed wetland system: Effects of hydraulic loading rate. Ecological Engineering, 36(4): 527-535.

Nurk K, Truu J, Truu M, Mander U, 2005. Microbial characteristics and nitrogen transformation in planted soil filter for domestic wastewater treatment. Journal of Environmental Science and Health, Part A: Toxic/Hazardous Substances and Environmental Engineering, 40(6-7): 1201-1214.

Olson R K, 1993. Created and Natural Wetlands for Controlling Nonpoint Source Pollution. CRC Press, Boca Raton. 142146.

Ong S A, Uchiyama K, Inadama D, Ishida Y, Yamagiwa K, 2010. Treatment of azo dye Acid Orange 7 containing wastewater using up-flow constructed wetland with and without supplementary aeration. Ecological Engineering, 101(23): 9049-9057.

Ouellet-Plamondon C, Chazarenc F, Comeau Y, Brisson J, 2006. Artificial aeration to increase pollutant removal efficiency of constructed wetlands in cold climate. Ecological Engineering, 27(3): 258-264.

Qu J H, Fan M H, 2010. The current state of water quality and technology development for water pollution control in China. Critical Reviews in Environmental Science and Technology, 40(6): 519-560.

Sakadevan K, Bavor H J, 1999. Nutrient removal mechanisms in constructed wetlands and sustainable water management. Water Science and Technology, 40(2): 121-128.

SEPA, 2009. Report on the state of the environment in China. Retrieved from http://english.mep.gov.cn/ standards_reports/soe/soe2009/201104/t20110411_208976.htm

Stottmeister U, Wießner A, Kuschk P, Kappelmeyer U, Kästner M, Bederski O et al., 2003. Effects of plants and microorganisms in constructed wetlands for wastewater treatment. Biotechnology Advances, 22(1-2): 93-117.

Tanner C C, Kadlec R H, Gibbs M M, Sukias J P S, Nguyen M L, 2002. Nitrogen processing gradients in subsurface-flow treatment wetlands-Influence of wastewater characteristics. Ecological Engineering, 18(4): 499-520.

Tanner C C, Kadlec R H, 2003. Oxygen flux implications of observed nitrogen removal rates in subsurface-flow treatment wetlands. Water Science and Technology, 48(5): 191-198.

Tanner C C, Sukias J P S, Upsdell M P, 1999. Substratum phosphorus accumulation during maturation of gravelbed constructed wetlands. Water Science and Technology, 40(3): 147-154

Toet S, Van Logtestijn R S P, Kampf R, Schreijer M, Verhoeven $\mathrm{J} T \mathrm{~A}, 2005$. The effect of hydraulic retention time on the removal of pollutants from sewage treatment plant effluent in a surface-flow wetland system. Wetlands, 25(2): 375391.

Vymazal J, 1999. Removal of $\mathrm{BOD}_{5}$ in constructed wetlands with horizontal sub-surface flow: Czech experience. Water Science and Technology, 40(3): 133-138.

Vymazal J, 2007. Removal of nutrients in various types of constructed wetlands. Science of the Total Environment, 380(1-3): 48-65.

Wießner A, Kuschk P, Stotmeister U, 2002. Oxygen release by roots of Typha latifolia and Juncus effusus in laboratory hydroponic systems. Acta Biotechnologica, 22(1-2): 209216. 